\title{
Process and Microbiological Quality of Soumbara (A Local Seasoning) Used in Côte d'Ivoire
}

\author{
Kouamé Kohi Alfred ${ }^{1,2, *}$, Bouatenin Koffi Maïzan Jean-Paul ${ }^{1}$, Coulibaly Wahauwouélé Hermann, \\ Kané Affissata Fathim France ${ }^{1}$, Camara Fatoumata ${ }^{1}$, Djé Koffi Marcellin ${ }^{1}$ \\ ${ }^{1}$ Department of Food Sciences and Technology, Laboratory of Biotechnology and food Microbiology, University of Nangui Ab- \\ rogoua, Abidjan, Côte d’Ivoire, \\ ${ }^{2}$ Food Security Research Group, Centre Suisse de Recherche Scientifique, Abidjan, Cote d'Ivoire.
}

How to cite this paper: Kouamé Kohi Alfred, Bouatenin Koffi Maïzan Jean-Paul, Coulibaly Wahauwouélé Hermann, Kané Affissata Fathim France, Camara Fatoumata, Djé Koffi Marcellin. (2020) Process and Microbiological Quality of Soumbara (A Local Seasoning) Used in Côte d'Ivoire. International Journal of the Science of Food and Agriculture, 4(4), 403-412.

DOI: $10.26855 /$ ijfsa.2020.12.007

Received: August 27, 2020

Accepted: September 30, 2020

Published: November 5, 2020

*Corresponding author: Kouamé Kohi Alfred, Department of Food Sciences and Technology, Laboratory of Biotechnology and food Microbiology, University of Nangui Abrogoua, Abidjan, Côte d'Ivoire; Food Security Research Group, Centre Suisse de Recherche Scientifique, Abidjan, Cote d'Ivoire.

Email: kohi.kouame@csrs.ci

\begin{abstract}
The present study aims at generating data that can produce useful information on the new trends in soumbara production processes and their effect on its microbiology quality. A descriptive survey was conducted in the production areas of Ferké, Katiola and Korhogo to determine the different production patterns. Samples of soumbara were collected in these production areas for microbiological analysis. The results show that regardless of the production area, there are two methods of producing soumbara. The differences were in the fermentation and cooking steps and the ingredients used. Microbiological analyses revealed the presence of mesophilic aerobic germs, total coliforms, Bacillus cereus and Staphylococcus aureus. The loads of mesophilic aerobic germs, Staphylococcus aureus and Bacillus cereus ranged from $(1.3 \pm 0.4) 10^{3}$ to $(1.2 \pm 0.3) 10^{4} ; 0$ to $(1.7 \pm 0.8) 10^{2}$ and $(1.1 \pm 0.1) 10^{1}$ to $(4.7 \pm 0.2) 10^{1} \mathrm{CFU} / \mathrm{g}$, respectively. The assessment of the marketable quality of the soumbara samples in accordance with Directive 2005/2073/EC on microbiological criteria for foodstuffs indicated acceptable microbiological quality for the Ferké and Katiola soumbara samples and unsatisfactory for the Korhogo soumbara samples.
\end{abstract}

\section{Keywords}

Soumbara, microbiological quality, fermentation

\section{Introduction}

Rapid urbanization in West Africa has contributed to the development of artisanal sectors for processing and marketing local agricultural products [1]. Several traditional processing processes have been developed both by the ingenuity of farmers and through research and development in the hope of improving the organoleptic and microbiological quality of these products. Among these processes, fermentation uses the metabolism of a real microbial "machinery" for bioconversion of plant substrates [2]. In the case of the fermentation of Nere (Parkiabiglobosa) seeds, this process makes it possible to obtain a condiment for sauces known in West Africa as soumbara in Côte d'Ivoire (also called soumbala in Burkina Faso and Mali, dawa-dawa in Niger and Nigeria, nététu in Benin and Senegal) [3]. Soumbara produced in Côte d'Ivoire is a flavouring agent used to enhance the taste of sauces and dishes, and is an important source of protein, lipids, carbohydrates, vitamins and trace elements [4]. In addition, soumbara in general is believed to have therapeutic benefits such as regulating blood pressure, jaundice, and preventing intestinal obstruction [5]. According to [4], soumbara, a product resulting from the fermentation of nere seeds, contains a microbial flora of biotechnological interest. However, the manufacture of these aromatic products is a relevant process that varies according to countries and ethnic groups. Its elaboration is long ( 4 to 5 days) and includes three essential steps: a double cooking of the seeds, a fermentation of the 
cotyledons and then a drying of the fermented product [6]. In addition, production is mainly carried out by small-scale production units, making quality control difficult. Also, preparation methods, such as the duration of fermentation, vary from one region to another or within ethnic groups, which affects the quality of the product [7].

The present study aims at generating data that can produce useful information on the new trends in soumbara production processes and their effect on its microbiology quality.

\section{Materials and methods}

\subsection{Data collection and sampling}

From August to November 2019, artisanal soumbara processors, randomly selected in 12 localities of 3 towns (Korhogo, Ferké, and Katiola) in northern parts of Côte d'Ivoire, were administered a questionnaire constructed and validated by a questionnaire expert group. Some of these cities (Korhogo, Ferké, and Katiola) are known to house people behind soumbara production. In collaboration with soumbara production units, a meeting was organized with selected groups of processors to explain them the objectives of the study. In addition, each participant was given verbal instructions on how to fill in the questionnaire and any other relevant information. The questionnaire was subjected to a preliminary validation on 15 production units to assess its clarity, the suitability of wording, and the average time needed for its completion. Based on this pilot study, necessary modifications were identified and resolved, whereas its results were not included in the final survey. The final questionnaire has been established and has been submitted to the staff on the different production site. All items were multiple-choice questions or statements with 2-6 possible answer choices including true/false and yes/no statements. The data used in this study were also collected by undisguised observations after obtaining the permission of soumbara production units owners to investigate and observe their practices during production in their premises. A total of 360 soumbara processors were included in the survey with 30 processors per locality.

After the survey, four (4) soumbara production units within each city were randomly selected and soumbara samples collected from processors within these units. In all, 12 processors were selected from the three soumbara producing towns and 5 samples per processor were collected from each selected production unit for microbiology analyses. All soumbara samples were collected from selected processors immediately after steaming in plastic bags as proposed by producers for retail selling. They were then transported in an icebox directly to the laboratory for analyses.

\subsection{Sample analyses}

Preparation of stock solutions, inoculation of agar plates, cultivation and quantification of micro-organisms were carried out according to [8]. For all determinations, $10 \mathrm{~g}$ of the samples was homogenized in a stomacher with $90 \mathrm{ml}$ of sterile buffered peptone water (AES Laboratoire, Combourg, France). Tenfold serial dilutions of stomacher fluid were prepared and spread-plated for determination of micro-organism counts.

Enumeration of coliforms was carried out using plates of Violet Red Bile Lactose agar (VRBL, Merck 10660, Merck, Darmstadt, Germany). The cultures were incubated for $48 \mathrm{~h}$ at $30^{\circ} \mathrm{C}$ for total coliforms and $44^{\circ} \mathrm{C}$ for faecal coliforms. The eosin methylene blue agar (Becton Dickinson GmbH, Heidelberg, Germany) was used to particularly enumerate and isolate E. coli, which grows on the medium giving a distinctive metallic green sheen colony. Aerobic mesophiles were enumerated on plates of plate count agar (PCA OxoidLtd, Basingstoke, UK) and incubated at $30^{\circ} \mathrm{C}$ for 2 days. Identification of the organisms isolated was based on cultural characteristics, morphology of cells and biochemicaltests. The media and reagents were prepared as described by $[9,10]$.

Staphylococcus aureus. Staphylococcus aureus was isolated and enumerated according to the method described by [11]. A volume of $0.1 \mathrm{ml}$ of each dilution was surface plated on Baird-Parker agar containing egg yolk tellurite emulsion (Oxoid) and incubated at $37^{\circ} \mathrm{C}$ for 24 and $48 \mathrm{~h}$. The total number of colonies, colonies with a typical morphology of Staphylococcus aureus and colonies with different morphology to those of Staphylococcus aureus were counted. Five colonies from each sample were randomly selected, purified and tested for cell morphology, arrangement of the cells, Gram reaction, catalase activity, oxidase test, ability to produce acid anaerobically in a glucose-containing growth medium, coagulase activity, thermo-stable nuclease activity, acid production from mannitol and acetoin production. Only, the gram-positive cocci were identified using the identification schemes proposed by [12]. After the identification, the percentages of Staphylococcus aureus and the other strains were calculated. These percentages were later used to correct the results of the counts obtained from each Baird-Parker agar plate.

The method of [13] was used. The tryptone sulphite neomycine (TSN) agar (Bio-Rad, Marnes-La-Coquette, France) was used forthe detection of Clostridium perfringens after a thermal shock of the dilutions $\left(80^{\circ} \mathrm{C}\right.$ for 15 min and immediately cooled). One (1) millilitre of each appropriate treated dilution was used to inoculate the tryptone sulphite neomycine TSN agar (Bio-Rad) stored in surfusion at $45^{\circ} \mathrm{C}$ in assay tubes. After the agar had solidified, all inoculated media were incubated in an upright position for $24 \mathrm{~h}$ at $46^{\circ} \mathrm{C}$. Tubes containing between 30 and 300 colonies were counted, and five colonies were picked for confirmation in motility-nitrate medium. The quantitative estimation of spores of $B a$ - 
cillus cereus was performed by a standard plate-counting method. Isolations were achieved from heat-treated dilutions by plating on mannitol egg yolk polymyxin B agar [14]. Presumptive colonies of Bacillus cereus were randomly selected based on characteristic colony feature, purified on the same medium and identified by morphological, cultural and biochemical characteristics according to the documented procedures [15]. The research of Salmonella in attieke samples was achieved according to the procedure described in the global Salmonella surveillance and laboratory support project of the World Health Organization [16]. From each sample, $25 \mathrm{~g}$ was aseptically weighed and macerated in $225 \mathrm{ml}$ of buffered peptone water (Oxoid) and incubated at $37^{\circ} \mathrm{C}$ for $24 \mathrm{~h}$. A selective enrichment in Tetrathionate broth (Muller-Kauffmann) and Rappaport Vassiliadis soy peptone broth using $1 \mathrm{ml}$ of previously incubated buffered peptone water was achieved at $37^{\circ} \mathrm{C}$ for $24 \mathrm{~h}$, followed by a subcultivationon Salmonella Shigella agar incubation at $35^{\circ} \mathrm{C}$ for 24-48 h [17]. Colourless, transparent and with a black centre colonies were further identified using biochemical tests.

\subsection{Data analysis}

Software R. 3-01, ANOVA method with Duncan's test, significance level 5\% was used. This software was used to calculate the means, standard deviation of microbiological parameters. It was also used to compare the means of the microbiological parameters of the samples and to determine whether the differences observed in the means of the microbiological parameters were significant at the $5 \%$ significance level. The survey data were processed using IBM SPSS software (Statistics 20).

\section{Results}

\subsection{Soumbara production process in Côte d'Ivoire}

Whatever the area of production, there are two methods of producing soumbara.

For method I, the néré pods are crushed to obtain the néré grains (Figure 1, Figure 2). The grains are washed and dried for eight (08) hours. The dried kernels are cooked for twenty-four (24) hours at $100^{\circ} \mathrm{C}$ (Figure 3). The grains after cooking are drained and then shelled with sand (Figure 4, Figure 5). The grains of sand facilitate dehulling. Once shelled, the grains are washed, floated and sieved to remove the sand and husks (Figure 6). The grains will be drained for 10 to 20 min and sorted to separate the unshelled and shelled grains. The shelled grains will be cooked for two to four hours. The cooked grains are placed in a basket covered with plastic film and left to ferment for 2 to 3 days in a warm place (Figure 7). The fermented grains were then covered with salt and shaped into pellets and dried for two to three days in the sun to obtain the ball-shaped soumbara (Figure 9) which could be ground to obtain powdered soumbara if desired.

For Method II, the néré seeds were first sorted by hand to separate the small seeds from the large ones, while separating the impure objects. These cleaned seeds were soaked in water for at least 30 minutes. The soaking softens the kernels to facilitate looting and also reduces the time of looting. The seeds are put in a mortar for shelling until the first skin is removed, the seeds are then dried this operation takes 5 hours (Figure 8). The peeled seeds were then boiled for 12 to 13 hours for a first cooking until they were easily prickly and red. The second hulling followed by washing the boiled seeds, which took 3 to 4 hours, then the seeds were then drained in a basket for 10 to 30 minutes. The seeds obtained in the previous step are put back into a pot containing water for a second cooking. The cooking process takes 1-2 hours. This step is essential because it eliminates possible pathogenic germs after the seeds have been touched several times by the hands during the treatment. The cooked Fines are put in fermentation for 40 hours. For this step, clean empty bags must be used. The seeds are poured into the empty bags with salt to speed up the fermentation process in some growers and then the bags are closed. After fermentation, the product is dried for milling to obtain powdered soumbara (Figure 10). On the other hand, when you want soumbara in granulated or ball form, you can do a pre-drying first, followed by balling. These results are shown in Figure 11.

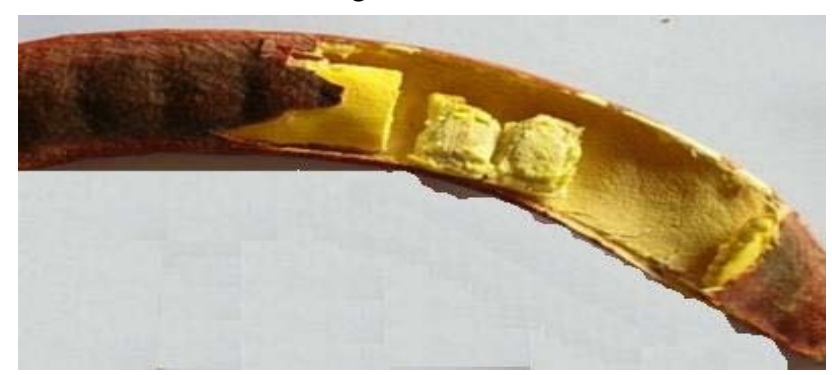

Figure 1. Pod of néré. 


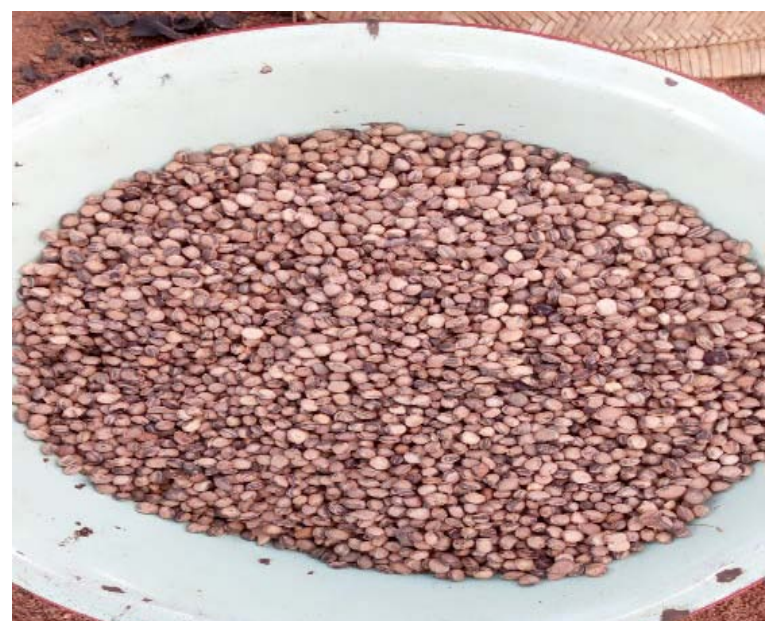

Figure 2. Grains of néré.

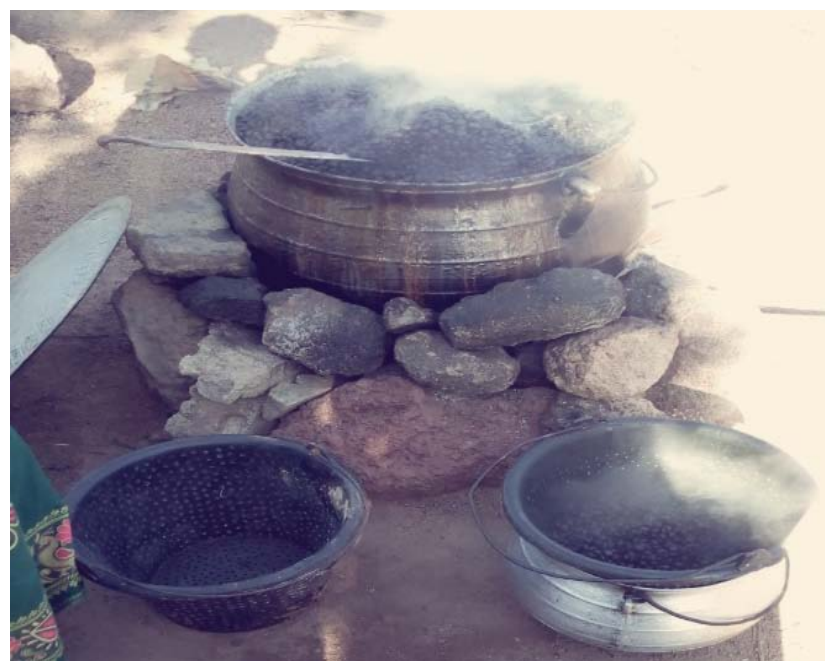

Figure 4. Drainage after cooking.

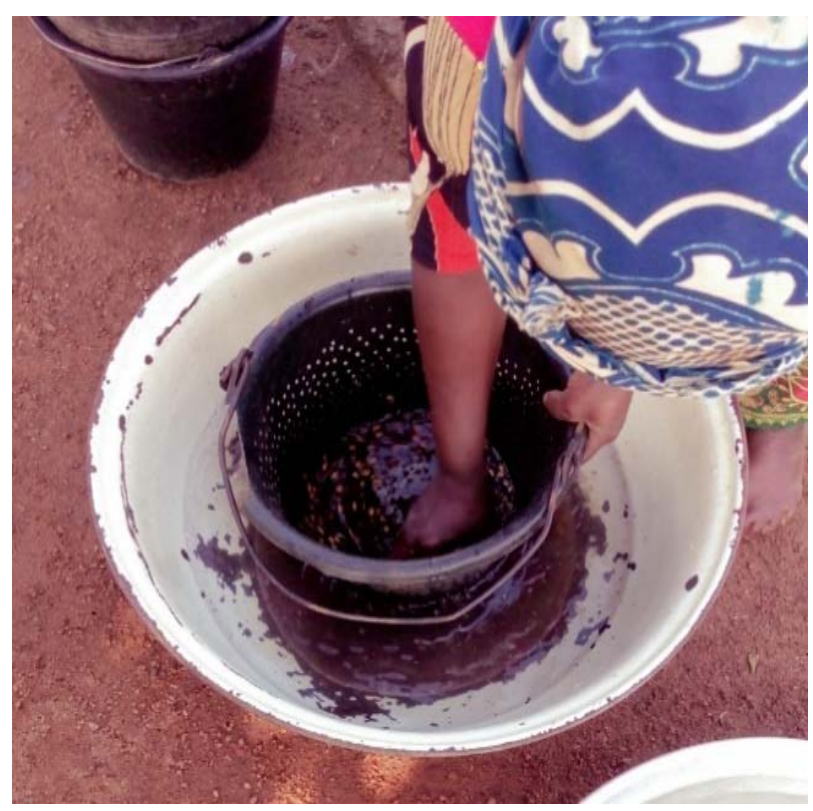

Figure 6. Washing and Drainage.

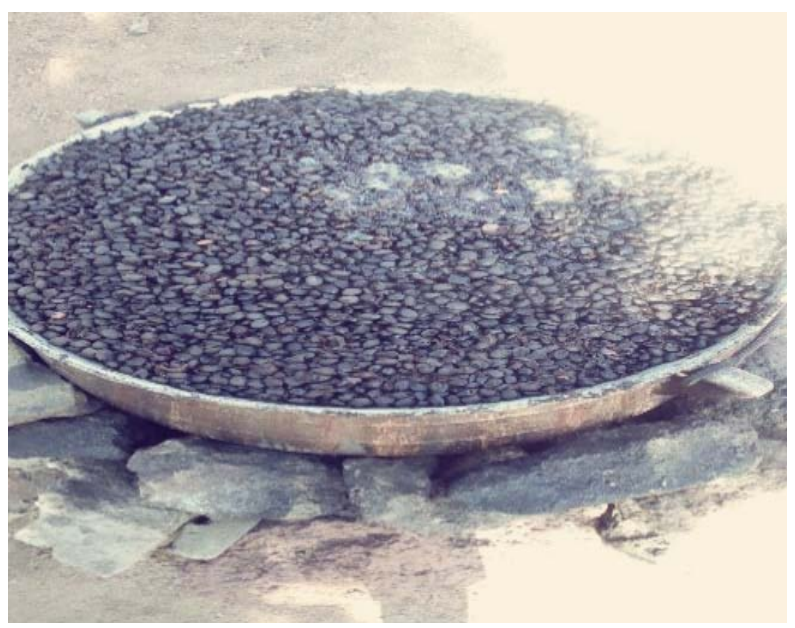

Figure 3. Cooking the grains.

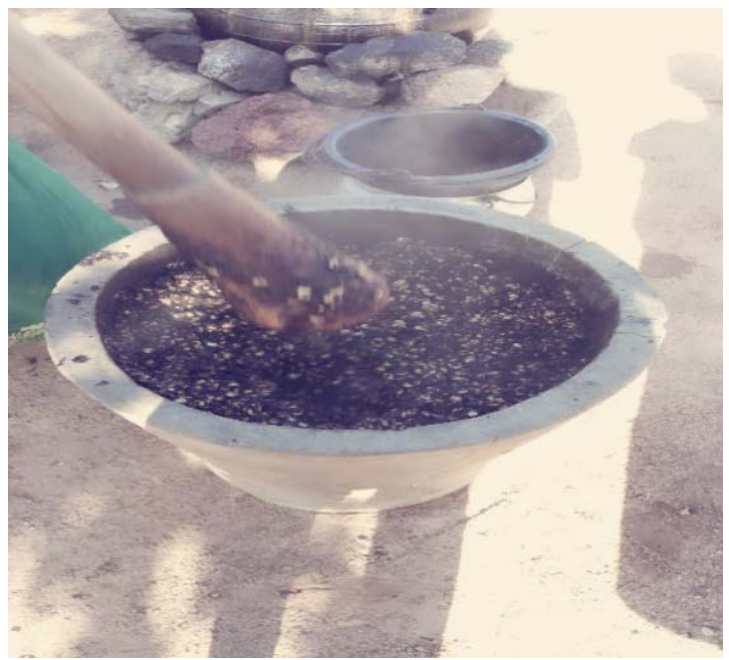

Figure 5. Grain hulling.

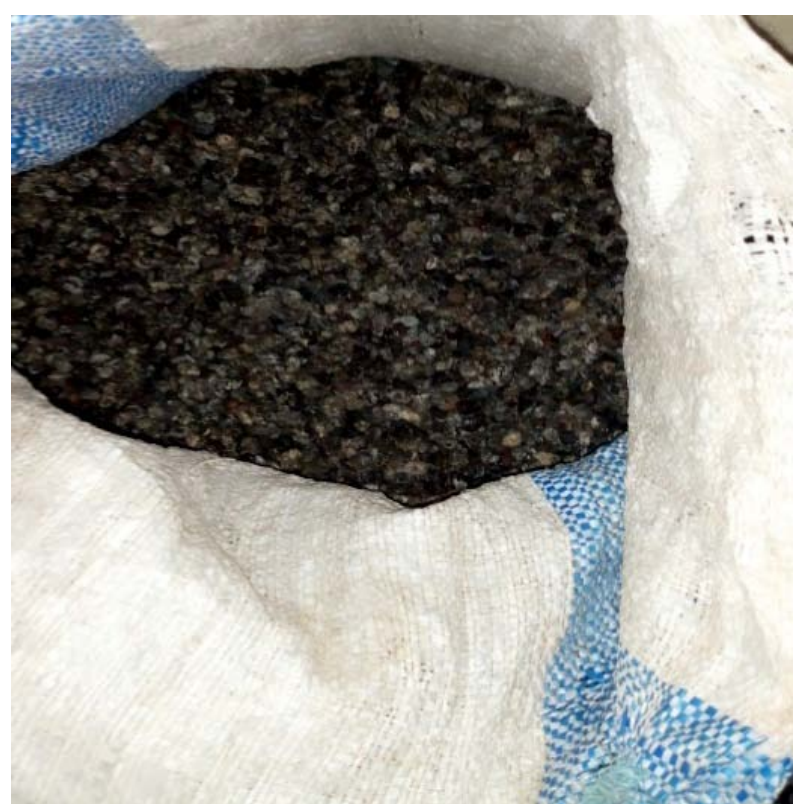

Figure 7. Fermentation. 


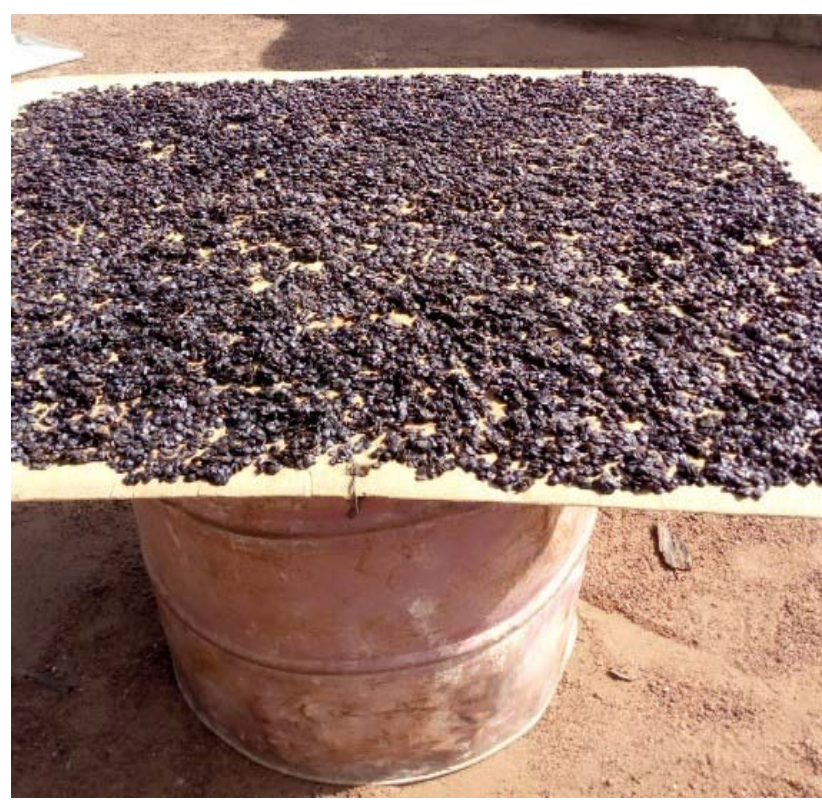

Figure 8. Drying.

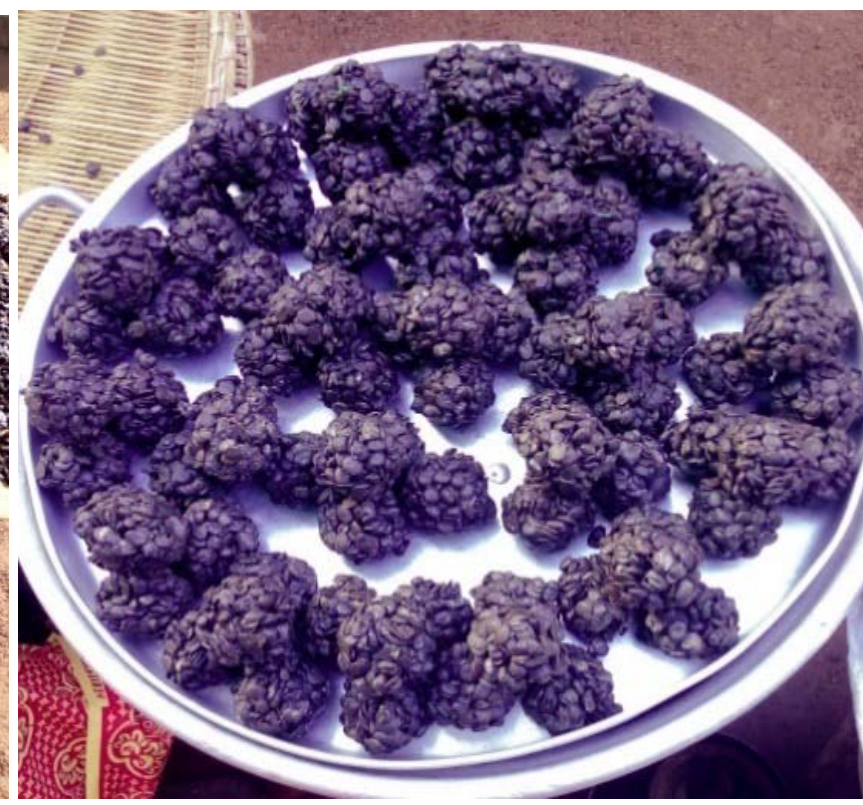

Figure 9. Moulding and drying.

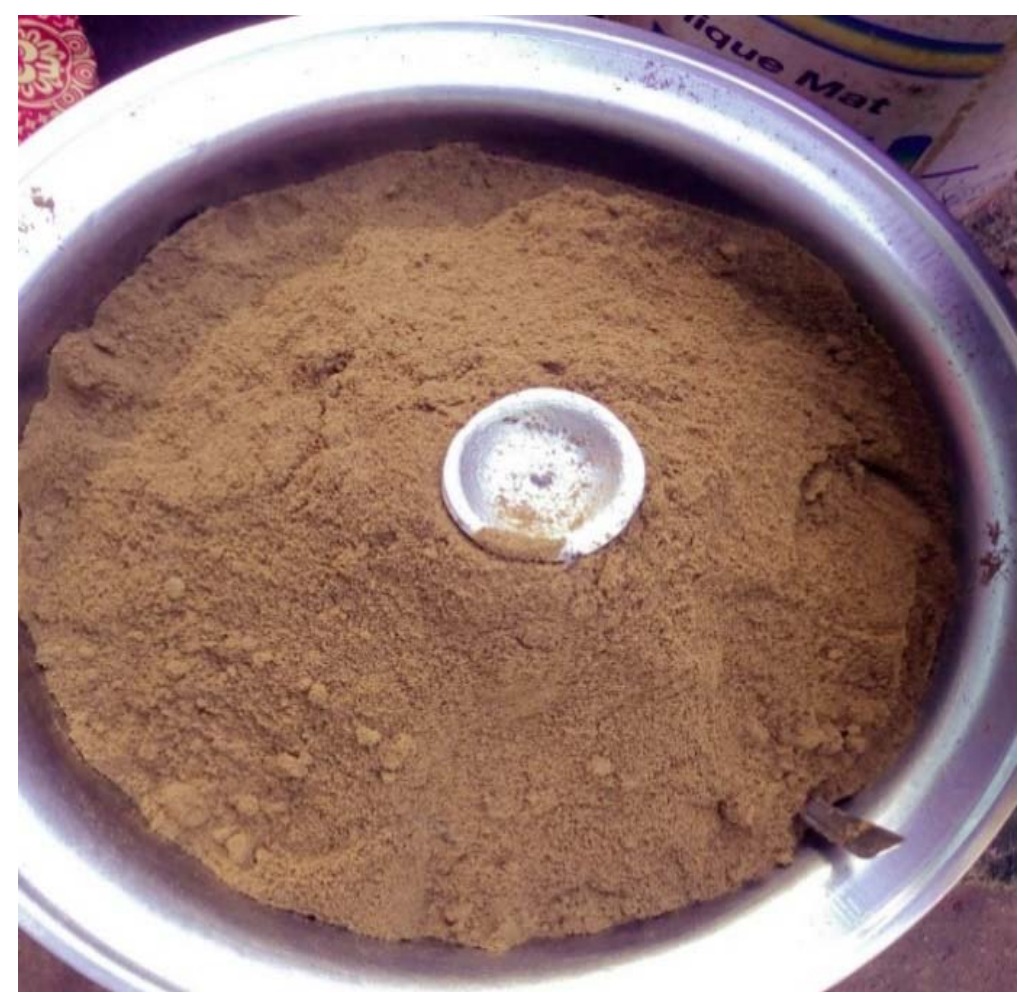

Figure 10. Soumbarapowder. 


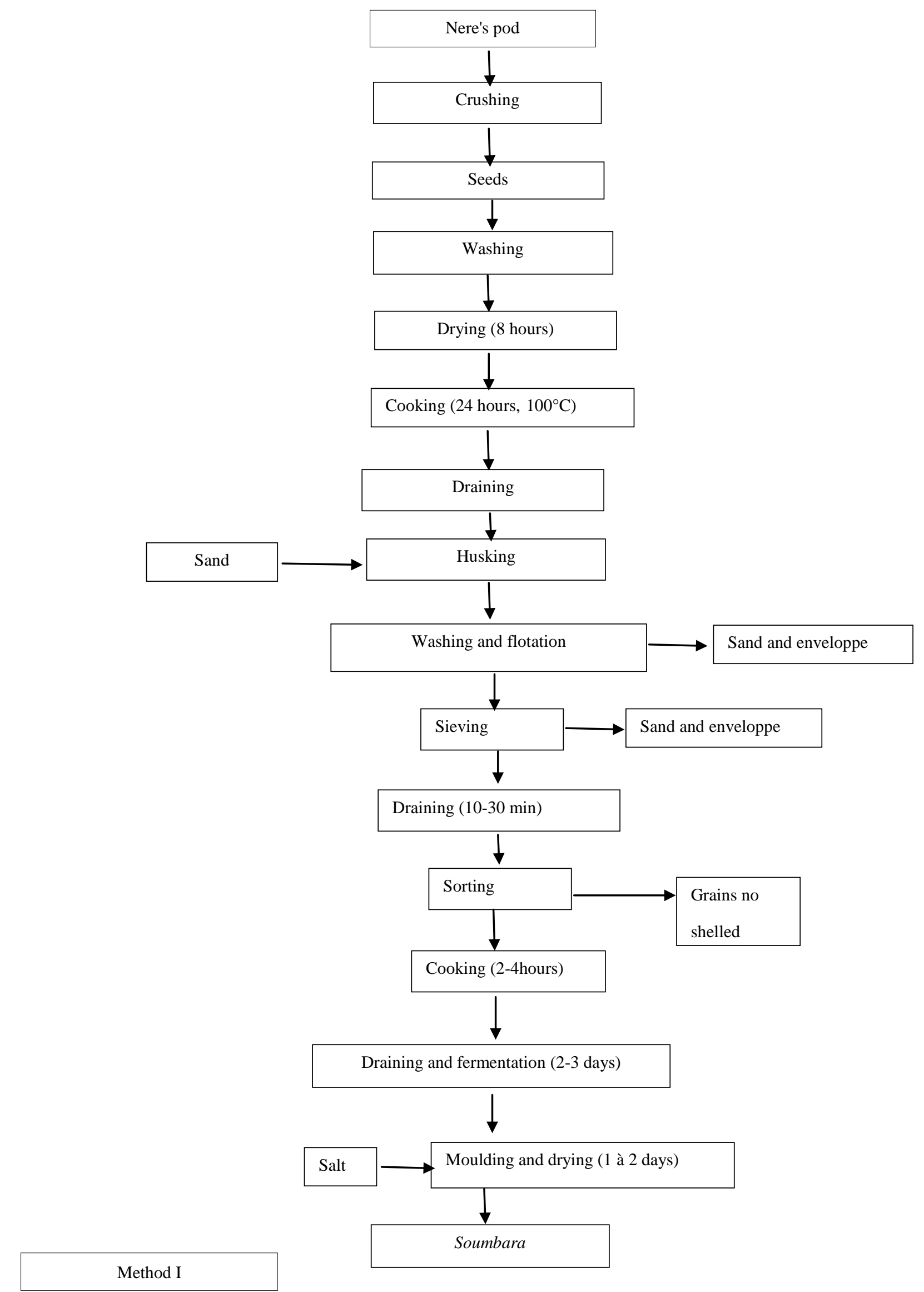



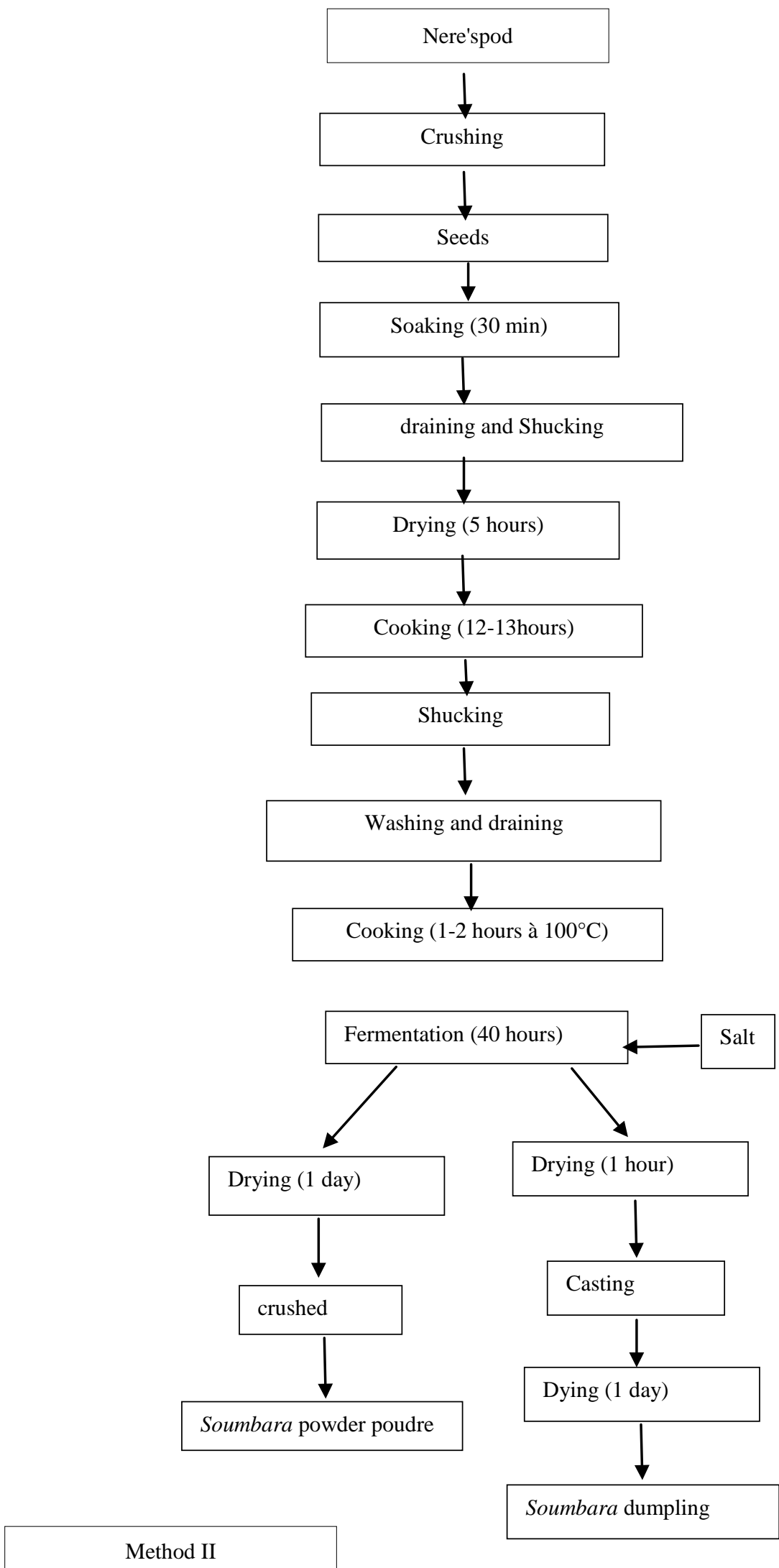

Figure 11. Production process of Soumbara in Côte d'Ivoire. 


\subsection{Microbial load of soumbara from the Korogho, Ferké and Katiola production areas}

In general, microbial loads of soumbara varied little from one producer to another within the same production area.

Soumbara produced in the Korhogo, Ferké and Katiola production areas did not contain Clostridium perfringens, Escherichia coli and Salmonella. However, soumbara from the production areas of Korhogo and Ferké was contaminated with mesophilic aerobic germs, total coliforms, Staphylococcus aureus and Bacillus cereus. Soumbara from the Korogho production area was more contaminated with mesophilic aerobic germs and Staphylococcus aureus with loads of $(1.2 \pm 0.3) 10^{4} \mathrm{CFU} / \mathrm{g}$ and $(1.7 \pm 0.8) 10^{2} \mathrm{CFU} / \mathrm{g}$ respectively. The one in the Ferke production area was more contaminated by Bacillus cereus and coliform bacteria with respective loads of $(4.7 \pm 0.2) 10^{1} \mathrm{CFU} / \mathrm{g}$ and $(1.9 \pm 0.1) 10^{1} \mathrm{CFU} / \mathrm{g}$. As for soumbara from the Katiola production area, it was contaminated by mesophilic aerobic germs and by total coliforms with respective loads of $(2.7 \pm 0.2) 10^{3} \mathrm{CFU} / \mathrm{g}$ and $(1.4 \pm 0.2) 10^{1} \mathrm{CFU} / \mathrm{g}$. Soumbara in the production areas of Ferké and Katiola are of satisfactory microbiological quality while Korhogo is of unsatisfactory microbiological quality because its mesophilic aerobic germs load was higher than the 2005/2073/EC standard (Table 1).

Table 1. Microbial load (CFU/g) of nere soumbara

\begin{tabular}{|c|c|c|c|c|}
\hline \multirow[t]{2}{*}{ Germs (CFU/g) } & \multicolumn{4}{|c|}{ Production zones } \\
\hline & Korhogo & Ferké & Katiola & Seuil \\
\hline GAM & $(1.2 \pm 0.3) 10^{4 \mathrm{a}}$ & $(1.3 \pm 0.4) 10^{3 \mathrm{~b}}$ & $(2.7 \pm 0.2) 10^{3 \mathrm{~b}}$ & $10^{6}$ \\
\hline Staphylococcus aureus & $(1.7 \pm 0.8) 10^{2 \mathrm{a}}$ & $(1.8 \pm 0.9) 10^{1 \mathrm{~b}}$ & 0 & $10^{2}$ \\
\hline Bacilluscereus & $(1.1 \pm 0.1) 10^{1 \mathrm{a}}$ & $(4.7 \pm 0.2) 10^{1 \mathrm{a}}$ & $(1.4 \pm 0.2) 10^{1 \mathrm{a}}$ & - \\
\hline Total coliforms & $(1.8 \pm 0.1) 10^{1 \mathrm{a}}$ & $(1.9 \pm 0.1) 10^{1 \mathrm{a}}$ & 0 & $10^{3}$ \\
\hline Clostridium perfringens & 0 & 0 & 0 & \\
\hline E. coli & 0 & 0 & 0 & \\
\hline Salmonella & absence & absence & absence & absence \\
\hline
\end{tabular}

On the same line, loads bearing the same letter have no significant difference at the 5\% threshold, GAM: Mesophilic Aerobic Germs; E. Coli: Escherichia coli;

\section{Discussion}

Soumbara production process was examined in the production areas of Korhogo, Ferké, and Katiola in northern Côte d'Ivoire with the aim of generating data that could provide useful information on the Soumbara production processes and how the microbiological quality of the products was affected and/or generated in the main processing areas. It was found that regardless of the production area, there were two production methods. The two methods differed in terms of cooking and fermentation times. This would be explained by the fact that the production areas are located in the north of the country and that these peoples have been producing this food since the dawn of time and the know-how is faithfully transmitted from generation to generation. Microbiological examination made it possible to assess the level of contamination of soumbara by non-fermentative microorganisms. The high load of mesophilic aerobic germs would favour a strong spoilage of soumbara and would constitute a risk of pathogenic germs [18]. This alteration flora, consisting of the total mesophilic aerobic flora with the highest content $(1.2 \pm 0.3) 10^{4} \mathrm{CFU} / \mathrm{g}$ would be of the same order of magnitude as (18.47) $10^{4} \mathrm{CFU} / \mathrm{g}$ reported by [19], in Guedji, a condiment based on fermented and dried fish. To this would be added Bacillus cereus, total coliforms and Staphylococci aureus. These microorganisms could degrade the products by altering the taste, smell, appearance, in short the marketable quality of soumbara [20]. The study indicated the absence of Salmonella and Anaerobic Sulfito-Reducing Anaerobes that would be due to the fermentation that makes the environment hostile to their growth [2]. The market quality assessment of the soumbara samples according to Directive 2005/2073/EC on microbiological criteria for foodstuffs indicated an acceptable microbiological quality for the Ferké and Katiola soumbara samples. On the other hand, due to their levels of Staphylococcus above the maximum acceptable value (100 CFU/g), the soumbara from Korhogo would be of unsatisfactory microbiological quality. This high load of Staphylococcus would be due to exposure to the open air during drying or sale but could also come from the hands of producers. However, corrective measures could help to reduce the Staphylococcus load. The absence of Salmoella, Clostridium perfringens and Echerichia coli in the samples would be the action of fermentative germs such as lactic acid bacteria that during fermentation not only produce bacteriocins but also acidify the environment which becomes unfavourable to these germs [21].

\section{Conclusion}

The present study aims at generating data that can produce useful information on the new trends in soumbara produc- 
tion processes and their effect on its microbiology quality. This study revealed that in Côte d'Ivoire there are two methods of soumbara production processes for nere in all production areas. Soumbara produced was contaminated with mesophilic aerobic germs and total coliforms but did not contain Clostridium perfringens, Escherichia coli and Salmonella. The assessment of the marketable quality of the samples of soumbara in accordance with Directive 2005/2073/EC on microbiological criteria for foodstuffs indicated an acceptable microbiological quality for the samples of soumbara from Ferké and Katiola and unsatisfactory for the samples of soumbara from Korhogo.

\section{Acknowledgements}

The authors gratefully acknowledge all the women soumbara producers.

\section{Competing interests}

Authors have declared that no competing interests exist.

\section{References}

[1] Cheyns, E., Bricas, N. (2003). La construction dela qualité des produits alimentaires: lecas dusoumbala, des céréales et des viandes sur le marché de Ouagadougouau Burkina Faso = Food product quality development processes. Case studies on soumbala, cerealand meat products on the Ouagadougou market. Montpellier : CIRAD, 82 p. (SérieALISA).

[2] Yao, A. A., Egounlety, M., Kouame, L. P., Thonart, P. (2009). Les bactéries lactiques dans les aliments ou boissons amylacés et fermentés de l’Afrique de l’Ouest : leur utilisation actuelle. Ann. Méd. Vét., 153: 54-65.

[3] Azokpota, P., Hounhouigan, D. J, Nago, C. M. (2006). Microbiological and chemicalchanges during the fermentation of African locust bean (Parkiabiglobosa) to produce afitin, iru, andsonru, three traditional condiments produced in Benin. International Journal of Food Microbiology, 107: 304-309.

[4] Diawara, B., Sawadogo, L., Kaboré, I. Z. (1992). Contribution à l'étude des procédés traditionnels de fabrication du Soumbara au Burkina Faso. Aspects biochimiques, microbiologies et technologiques. Sciences et Techniques 20, 5-14 CNRST, Ouagadougou, Burkina Faso).

[5] Camara, F., Soro, S., Traore, S., Brou, K., Djé, K. M. (2016). Caractéristiques biochimiques etmicrobiologiques de moutardes africaines produites à base de graines fermentées de Parkiabiglobosa et de Glycine max, vendues en Côte d’Ivoire. Int. J. Biol. Chem. Sci. 10(2): 506-518.

[6] Ahouansou, R. H. (2012). Contribution à la mise au point et à l'optimisation deséquipements detransformation agroalimentaire au Bénin : Cas de la décortiqueuse de néré et de la presse d'afitin. Thèse de Doctorat Unique de l’Université d’Abomey-Calavi, 285p.

[7] Camara, F. (2016). Valorisation du soumbara, un condiment local issu de la fermentation des graines de néré (Parkiabiglobosa) ou de soja (Glycin max), vendu en Côte d'Ivoire : aspects socio-économiques, microbiologiques, nutritionnels et thérapeutiques. Thèse de doctorat unique, Université NanguiAbrogoua, UFR des Sciences et Technologies des Aliments, 147 p.

[8] Djéni, N. T., N’Guessan, K. F., Toka, D. M., Kouame, K. A., Dje, K. M. (2011). Quality of attieke (a fermented cassavaproduct) from the three main processing zones in Côte d'Ivoire. Food Res Int 44, 410-416.

[9] Harrigan, W. F., McCance, M. E. (1976). Laboratory Methods in Food and Dairy Microbiology. London: Academic Press, pp. 66-81.

[10] Speck, L. (1976). Compendium of Methods for the Microbiological Analysis of Food. Washington, DC: American Public Health Association, pp. 417-483.

[11] Capita, R., Alonso-Calleja, M. C. B., Garcia-Fernandez, M. C. (2001). Assessment of Baird Parker agar as screening test for determination of Staphylococcus aureus in poultry meat. Journal of Microbiology, 39: 321-325.

[12] Schleifer, K. H., Kloos, W. E. (1975). Isolation and characterization of staphylococci from human skin. Int J Syst Bacteriol, 25, 50-61.

[13] Harmon, S. M., Kautter, D. A., and Peeler, J. T. (1971). Comparison of media for the enumeration of Clostridium perfringens. Appl Microbiol, 21, 922-927.

[14] Mossel, D. A. A., Koopman, M. J., Jongerius, E. (1967). Enumeration of Bacillus cereus in foods. Appl Microbiol, 15, 650-653.

[15] Cappucino, J. G., Sherman, N. (2004). Microbiology: A Laboratory Manual, $6^{\text {th }}$ ed. Singapore: Person Education, pp. $133-198$.

[16] Hendriksen, R. S. (2003). Laboratory Protocols Level 1: Training Course Isolation of Salmonella. A Global Salmonella Surveillance and Laboratory Support Project of the World Health Organization, 4th ed. Geneva: WHO.

[17] Feng, P., Weagant, S., Grant, M. (2007). Enumeration of Escherichia Coli and the Coliform Bacteria. Bacteriological Analytical Manual, 8th ed. USA: FDA/Center for Food Safety and Applied Nutrition.

[18] Kasse, M., Cisse, M., Toure, A., Ducamp-collin, M. N., Guisse, M. (2014). Qualité microbiologique des tranches de mangues 
(Mangiferaindica L.) vendues à Dakar (Sénégal). Int. J. Biol. Chem. Sci., 8(4): 1611-1619.

[19] Fall, N. G., Tounkara, I. L. T., Diop, M. B., Thiaw, O. T., Thonart, P. (2014). Etudesocioéconomique et technologique de la production du poisson fermenté et séché (Guedj) au Sénégal. Int. J. Biol. Chem. Sci., 8(6): 2523-2538.

[20] Lortal, M. (2015). Ferments et aliments : unelongue histoire riche d'enseignements. Innovation Agronomiques, $44:$ 1-13.

[21] Kouamé, K. A., Bouatenin, K. M. J-P., Djéni, N. T., Dje, K. M. (2019). Identification of hazards and critical control points during attiéké (a fermented cassava product) process in Côte d’Ivoire. Letters in AppliedMicrobiology, 70, 87-94. 